\title{
Language policy and the reconceptualization of religions as and in institutions
}

\author{
Netta Avineri · Sharon Avni
}

Received: 6 February 2015/Accepted: 14 February 2015/Published online: 21 March 2015

(C) Springer Science+Business Media Dordrecht 2015

\section{Lived religion, institutions, and decision-making}

This special issue considers the diverse ways that the field of language policy intersects with the study of "lived religion": religious practices and imagination in ongoing, dynamic relations with the realities and structures of everyday life in particular times and places (Orsi 2002, p. xiii). In recent years, the idiom of lived religion has marked a clear departure from the binary distinctions of public/private, sacred/mundane, and institutional/individual to a closer analysis of the dialectical relationship between them (Bender 2003). For the field of language policy and planning, examining how individuals and groups conceptualize language(s), invest in their meanings, and use them to talk about and practice religion allows us to see how religious language policy is inherently connected to and penetrates everyday life. Such a perspective situates religious language policy as a form of cultural work and underscores the role of language ideologies in shaping what are considered legitimate practices, sanctioned ways of learning, and authentic theologies.

Lived religion does not discount the influence that official religious institutions wield nor does it neglect organized religion; rather, it questions what counts as an institution and who decides. Governments, schools and religious establishments have traditionally been seen as sites for (especially top-down) language policy. But can families, with their implicit and explicit norms and expectations, be considered

\footnotetext{
N. Avineri ( $\square)$

Middlebury Institute of International Studies at Monterey, 460 Pierce St, Monterey, CA 93940, USA e-mail: navineri@gmail.com
}

\section{S. Avni}

Borough of Manhattan Community College, The City University of New York, 199 Chambers Street, New York, NY 10007, USA

e-mail: savni@bmcc.cuny.edu 
institutions? Can a set of ideologies function like an institution, with all of the affordances therefore involved? The papers in this special issue examine the nested nature of institutions as they relate to historical and contemporary language policy phenomena.

All of the papers discuss the decisions of families, communities, and various historically-relevant groups, which are influenced by broader theological, linguistic, social, educational, and historical trends. The authors highlight the role of multilingualism in religious language policy, emphasizing the centrality of choice and decision-making. There is a range of codes, registers, and varieties available in these contexts, which individuals and communities select from strategically to take up particular ideological stances. This framing of religious policy through the lens of decision-making can be used in the service of differentiating, establishing, validating, legitimizing, and balancing the past, present, and future. By expanding the category of potential decision makers, this special issue highlights the ways that religious language policy is negotiated in day-to-day practices.

Using a range of macro- and micro-oriented methodologies, including ethnography and discourse analysis, the authors in this issue shine attention on institutions and people, texts and discourses, practices and theology, and ideologies and actions. Longitudinal, ethnographic language socialization approaches are used to understand particular contexts in-depth and over time. Discourse analysis of historical documents and written texts (as indexical of particular ideologies) and language practices are also employed as ways to understand the micro-level interactions that shape religious language policy. By acknowledging all of these interconnected phenomena, this collection offers a novel approach for uncovering how language policy in all its forms shapes and reflects everyday practice within a matrix of relations that encompass broader theological, linguistic, social, educational, and historical considerations.

\section{Lived religion and language ideologies}

Language ideologies, a "mediating link between social structures and forms of talk" (Woolard and Schieffelin 1994, p. 55), are centrally relevant to this examination of language policy as lived religion. Participants demonstrate their ideologies through both their discursive consciousness and practical consciousness (Giddens 1984). As Spitulnik (1998) highlights, "Language ideologies and processes of language valuation are never just about language (Kulick 1998; Woolard and Schieffelin 1994, pp. 55-56). Language ideologies are, among many other things, about the construction and legitimation of power, the production of social relations of sameness and difference, and the creation of cultural stereotypes about types of speakers and social groups" (p. 164). Or's paper emphasizes ideologies about having a "new" language to represent the "new" Israel nation. However, this language was not novel if evaluated based upon certain criteria, and ideologies around tradition and modernity are connected to these judgments. Particular lexical items simultaneously become iconic of both tradition and modernity, therefore demonstrating fractal recursivity, "the projection of an opposition, salient at some level of relationship, onto some other 
level" (Irvine and Gal 2000, p. 37). Warner-Garcia's paper highlights how certain discourse genres and topics are preferred over others, and also create situations of erasure, "the process in which ideology, in simplifying the sociolinguistic field, renders some person or activities (or sociolinguistic phenomena) invisible" (Irvine and Gal 2000, p. 37). In Hoenes del Pinal's discussion, ideologies about what language is the natural, moral, and authoritative code for religious practice become central. And ideologies about language learning, in particular of "sacred languages," become salient in the Fulbe communities that Moore explores. Ideologies, and their public performances, shape religious language policy across these contexts.

\section{Lived religion and "sacred" languages}

Attending to language policy as lived religion draws us away from stark dichotomies like secular and sacred, and suggests that so-called religious languages are always in the process of negotiation along a spectrum of legitimization and authenticity. In his discussion of Yiddish as a holy language, Fishman (2002) notes, "Holiness not only varies along a historical continuum (hitherto non-holy languages having holiness bestowed upon them and, in the opposite direction, once-holy languages being secularized and desanctified), but holiness can be a matter of degree and of startlingly different imagery in different social circles that are contemporary" (p. 125). But, are there gains or losses when these notions are conflated? A number of questions rise to the surface here: What is a sacred language, and who has the authority to decide or challenge this? How do these terms change as other historical/social changes take place? If a secular language offers comprehensibility, or secular practices (e.g., ways of reading) offer a sacralizing possibility, is the difference material or ideological?

In his discussion of "sacred" words used for "secular" nationalizing purposes, Or's paper highlights in particular the difficulty of determining any boundaries between the secular and the sacred and between modernity and tradition. Moore's "secular" is a type of education modernization, seen as distinct from the desire to know and learn Arabic as a language of tradition. Warner-Garcia's paper emphasizes the topic of sexuality (considered secular) as negotiated within a sacred institution-using a "secular" discourse of dialogue/conversation/narrative to discuss church beliefs/doctrine. And Hoenes del Pinal's article calls into question which language is the secular one when both Charismatics and mainstream Catholics make contesting claims to authority and legitimacy. When the Catholic Church did away with the Latin service, how does a vernacular language become sacred, and to whom? And who decides?

\section{Summaries of special issue papers}

In her paper, "Change and Variation in Family Religious Language Policy in a West African Muslim Community," Leslie Moore employs longitudinal ethnographic methods to examine the decisions Maroua Fulbe parents in the African country of 
Cameroon make regarding their children's acquisition of Arabic as part of their broader Muslim education. Rather than only taking a comparative look at the dynamics of language variation within each of seven focal families, Moore widens her analytic lens to consider how these families' language policies intersect with larger linguistic, social, cultural, and educational changes in the community and the broader region. In doing so, she brings into focus how the new Islamic resurgence movements, active since the 1990s, have increased access to religious mediatization through satellite TV, DVD's, and print materials, thereby making the population less dependent on local religious leaders for Islamic knowledge or traditional methods of teaching. In addition, these movements have shifted what it means to know Arabic and what the definition of the competent Arabic learner might be. Central to this reorientation is a noted move from the sacrality orientation, with its emphasis on the reverent, sacred and mystical aspects of Arabic, to a comprehensibility orientation, which de-emphasizes the form in favor of understanding content (Liddicoat 2012). Moore demonstrates how families negotiate these shifts, including collective Qur'anic instruction in French, a public school-like curriculum, and instruction in Arabic that uses second/foreign language "modern" theories and methods that highlight the propositional content of Arabic texts. Combining family language policy with religious language policy, Moore's articles rejects the assumption that religious language policies are either local or transnational, topdown or bottom up. Rather, she underscores the complex ways in which intimate family language decisions shape and are shaped by broader considerations regarding what is a religious language, how its competency is defined, how it is acquired, and how these processes are steeped in both traditions of the past and imaginaries of the future. In this way, Moore suggests that families, with their implicit and explicit norms and expectations, can be considered institutions wielding significant power over how religious life is experienced in daily family practices.

Warner Garcia's "Rejecting exclusion, embracing inclusion: Conversation as policy-making at a U.S. Baptist conference on sexuality and covenant" challenges the directionality of religious language use, arguing that discourse is both a creator and product of language policy. Analyzing how the leadership of the Baptist Conference on Sexuality and Covenant in Atlanta, Georgia, 2012 explicitly avoided setting a policy regarding issues of sexuality and religion, Warner Garcia also refutes the notion that institutional settings are the prime agents of policy-making discourses. Rather, she demonstrates how conference conveners advertised, structured and executed the gathering as a "conversation," thereby discursively constructing it as a site of casual and equitable negotiation that promoted inclusion over exclusion. She shows that through employing the term covenant the conveners stressed interpersonal goals, such as respect, understanding and openness over institutional goals, such as issues and positions. Yet, her ethnographic approach reveals that the conversation-as-policy framework was not without boundaries or critics, and that this speaking genre was not entirely open to all participants, opinions, or directions. Not only did the very nature of a Baptist conference at times presuppose and rely on established Church policy on sexuality, but the contours of conversation required tremendous institutional scaffolding and limitations. Warner Garcia reminds us that all types of discourse-both institutional and non- 
institutional-may be used in the service of religious language policy, as religious groups use language to not only encode policy but to determine and validate theological beliefs and values.

Iair Or's paper, "'A seed blessed by the Lord': The religious of religious expressions in the creation of Modern Hebrew" takes on the oft-studied topic of the successful revitalization of Hebrew as the daily vernacular of the modern state of Israel, but offers a fresh and important look at the historical discussions regarding Hebrew language planning in Palestine and Israel in the years 1890-1953. Diving into historical archives, Or refutes the argument that the Zionist project in the late 1800 and early 1900s was wholly driven by nationalistic and secular motivations. Whereas it is well known that Hebrew was chosen over Yiddish and other languages as a clear representation of the new modern nation, Or expands this understanding by looking carefully at the Proceedings of the Hebrew Language Committee, the main official body responsible for language planning during Ottoman and Britishruled Palestine. His article demonstrates that members of the committee infused their language-creating and standardizing deliberations with religious imagery and expressions that drew from references to Jewish law, religious notions of sanctity and purity and Jewish history. Using written textual data, Or's work not only breaks down the boundaries between secular and religious language policy, showing how in fact, they are intertwined and co-constructed, but also craftily reveals how lexical items may be indexical of a range of ideologies. His wider contribution to religious language policy calls for closely examining the deliberative processes of language planning at particular historical moments and questioning the "religious residue" of language policies that seek to secularize a language and strip it of its sacredness for nationalistic and other social gains.

Hoenes del Pinal's contribution, "From Vatican II to speaking in tongues: Theology and language policy in a Q'eqchi'-Maya Catholic parish" underscores the dynamic and fluid nature of religious language policy, theology, and local interests, challenging the notion that top-down language policy is interpreted and enacted in predictable and uncontested ways. Tracing the decision of Vatican II to allow local parishes to utilize the vernacular in the liturgy, Hoenes del Pinal analyzes how members of a Q'eqchi'-Maya community in Guatemala engaged in a hoary debate regarding which local vernacular-Q' eqchi or Spanish—should be used as a means of articulating and authenticating Catholic theology, principles and beliefs. Hoenes del Pinal shows that mainstream Catholics subscribe to a form of linguistic purism in which Q'eqchi liturgical monolingualism is imbued with sacrality, naturalness, morality, and authority. To achieve this, mainstream Catholics strongly reject Charismatic Catholics' self-conscious and deliberate use of Spanish (along with certain prosodic and stylistic features) claiming that the latter are evangélicos (i.e. Protestants)_corrupting and illegitimate forces. Charismatic Catholics, on the other hand, not only challenge the purported ethnolinguistic homogeneity of the community and mark their difference through Spanish, but also make their own theological claims that Spanish-Q'eqchi multilingualism is a means of joyous, unmitigated and unmediated engagement with the divine. Countering that spontaneous code switching, ebullient singing and glossolalia are signs of God's grace upon the congregation, Charismatics define their spirituality through language 
choice. Hoenes del Pinal's rich ethnographic and historically-contingent study points to how macro-level language policies are refracted and shaped in local conditions, as both congregations' logics authorize and legitimize their linguistic practices vis-à-vis core theological tenets, and enact distinct ways of being Catholic and Maya, all the while adhering to the language policies of the Catholic Church.

The idiom of lived religion provides a robust frame for examining the intersection of language ideologies and practices within religious life. These four contributions challenge notions of religious language policy as fixed and immutable and show how like religion itself, religious language policy comes into being in an ongoing, dynamic relationship with the realities and verisimilitude of everyday life (Orsi 1997). Examining how religious practices and understandings only have meaning when connected to other cultural forms and in relation to the histories, life experiences, and tangible circumstances of the people and organizations using them, religious language policy can be conceptualized as an institution and in institutions, and opens up a new avenue for both methodological and theoretical exploration.

Acknowledgment We would like to thank Elana Shohamy and Kendall King for their guidance in this special issue's conception and development. We would also like to thank the articles' reviewers for their insightful comments and feedback.

\section{References}

Bender, C. (2003). Heaven's kitchen: Living religion at God's Love We Deliver. Chicago, IL: University of Chicago Press.

Fishman, J. A. (2002). The holiness of Yiddish: Who says Yiddish is holy and why? Language Policy, $1,123-141$.

Giddens, A. (1984). The constitution of society. Berkeley: University of California Press.

Irvine, J. T., \& Gal, S. (2000). Language ideology and linguistic differentiation. In P. V. Kroskrity (Ed.), Regimes of language (pp. 35-83). Santa Fe, NM: School of American Research Press.

Kulick, D. (1998). Anger, gender, language shift, and the politics of revelation in a Papua New Guinean village. In B. B. Schieffelin, K. A. Woolard, \& P. V. Kroskrity (Eds.), Language ideologies: Practice and theory (pp. 87-102). New York: Oxford University Press.

Orsi, R. (1997). Everyday miracles: The study of lived religion. In D. Hall (Ed.), Lived religion in America: Toward a history of practice (pp. 3-21). Princeton, NJ: Princeton University Press.

Orsi, R. (2002). The Madonna of $115^{\text {th }}$ street. Faith and community in Italian Harlem, 1880-1950. New Haven, CT: Yale University Press.

Spitulnik, D. (1998). Mediating unity and diversity: The production of language ideologies in Zambian broadcasting. In B. B. Schieffelin, K. A. Woolard, \& P. V. Kroskrity (Eds.), Language ideologies: Practice and theory (pp. 163-188). New York: Oxford University Press.

Woolard, K. A., \& Schieffelin, B. B. (1994). Language ideology. Annual Review of Anthropology, 23, 55-82.

Netta Avineri is TESOL/TFL Visiting Professor at the Middlebury Institute of International Studies at Monterey. Her research interests include language socialization, heritage and endangered language pedagogy, and service-learning. She has published in the Journal of Linguistic Anthropology, Language \& Communication, Anthropology News, and Issues in Applied Linguistics, as well as in the Handbook of Heritage, Community, and Native American Languages in the United States: Research, Educational Practice, and Policy. She has taught Anthropology, Applied Linguistics, Education, ESL/Writing Programs, History, Linguistics, Service-Learning, and Sociology at UCLA, UC Berkeley, UC Santa Cruz, 
CSU Long Beach, CSU Monterey Bay, and Pierce College. She is an Associate Editor for the Heritage Language Journal and a Core Member of the American Anthropological Association's Committee for Human Rights Task Group/Society for Linguistic Anthropology Committee on Language \& Social Justice.

Sharon Avni is Assistant Professor of ESL and Linguistics at BMCC, City University of New York (CUNY). Her scholarly interests focus on Hebrew language learning, religious materiality, language ideologies, and religious language policy. She is a research affiliate at the Mandel Center for Studies in Jewish Education at Brandeis University and is working on an interdisciplinary study examining Hebrew at American Jewish residential camps. Her current research is on media conceptions of language encroachment and religious endangerment as they relate to Hebrew language charter schools. Her articles appear in International Journal of Sociology of Language, Journal of Jewish Education, Current Issues in Language Planning, Language Policy, Linguistics and Education, Narrative Inquiry, and Language in Society. She has also co-edited a special issue on Jewish education in Diaspora, Indigenous, and Minority Education. 